ISSN 1027-5495. Functional Materials, 25, No.2 (2018), p. 386-390

\title{
Enhance the viscosity properties of ball-shaped Carbonyl iron based magnetorheological fluid by adding glass particles
}

\author{
CHEN Bingsan ${ }^{1,2}$, LAI Xiaobin ${ }^{1}$, LI Chunyu ${ }^{1}$ \\ ${ }^{1}$ Department of Mechanical Engineering and Automotive, Fujian \\ University of Technology, Fujian, China,3501182 \\ ${ }^{2}$ Digital Fujian Industrial Manufacturing IOTLaboratory, \\ Fuzhou 350118, China
}

Received January 30, 2018

\begin{abstract}
In this study, the effect of nonmagnetizable glass particles to the viscosity properties of the ball-shaped Carbonyl iron based magnetorheological fluid containing a mixture of magnetizable and nonmagnetizable particles were investigated. Two different MR fluids with different mass fraction of Carbonyl iron and glass particles were tested in the experiments. Experiment results show that the viscosity is greatly improved when the glass particles are added in the magnetorheological fluid. When the added glass particles mass fraction up to $10 \%$, the viscosity is at the highest value under the application of the currents, nearly 7 times larger than MRF-60 without glass particles. MRF-60, MRF-65 two different magnetorheological fluids exhibits similar phenomena. The proper amount of glass particles can enhance the viscosity of the magnetorheological fluid.
\end{abstract}

Keywords: magnetorheological fluid; nonmagnetizable glass particles; viscosity; enhanceemnt

Исследовано влияние немагнитных частиц стекла на вязкостные свойства магнитореологической жидкости на основе карбонового железа на основе карбона, содержащей смесь магнитных и немагнитных частиц. В экспериментах были испытаны две разные МР-жидкости с разной массовой долей карбонильного железа и частиц стекла. Результаты эксперимента показывают, что вязкость значительно улучшается при добавлении частиц стекла в магнитореологическую жидкость. Когда добавленная массовая доля частиц стекла до 10\%, вязкость находится на самом высоком значении при применении токов, почти в 7 раз превышающих MRF-60 без стеклянных частиц. MRF-60, MRF-65 имеют две разные магнитореологические жидкости с аналогичными явлениями. Правильное количество частиц стекла может повысить вязкость магнитореологической жидкости.

В’язкі властивості магнітореологіческой рідини на основі карбонового заліза 3 додаванням часток скла. CHEN Bingsan, LAI Xiaobin, LI Chunyu

Досліджено вплив немагнітних частинок скла на в'язкісні властивості магнітореологіческой рідини на основі карбонового заліза на основі карбону, що містить суміш магнітних і немагнітних частинок. В експериментах були випробувані дві різні МР-рідини з різною масовою часткою карбонільного заліза і частинок скла. Результати експерименту показують, що в'язкість значно поліпшуеться при додаванні частинок скла в магнітореологіческой рідина. Коли додана масова частка частинок скла до 10\%, в'язкість знаходиться на найвищому значенні при застосуванні струмів, майже в 7 разів перевищують MRF-60 без скляних частинок. MRF-60, MRF-65 мають дві різні магнітореологіческой рідини з аналогічними явищами. Правильне кількість частинок скла може підвищити в'язкість магнітореологіческой рідини. 


\section{Introduction}

Magnetorheological (MR) fluid is one a kind of smart material [1,2], which are composed of base fluid and suspended particles. The important and interesting feature of MR fluid is the fast and reversible continuous phase transition, which can be changed from a liquid to solid-like structure with the application of magnetic field (Guangshuo et.al, 2017). This MR effect induces the change in apparent viscosity and yield stress. The greater the variation range in apparent viscosity between under magnetic field and without magnetic field, the better controllability of the MR fluid. Therefore, MR fluid has been studied and developed for many devices, such as brake [3,4], shock absorber [5], highprecision polishing [6,7].

MR fluid is a mixture mainly composed of base fluid and suspension phase. Silicone oil is usually used as the base fluid, while softmagnetic carbonyl iron particles are commonly used as the suspension phase for MR fluid due to their high saturation magnetization, favorable magnetic permeability and suitable particle size [8]. In order to obtain higher MR effect researchers have done a lot of studied on the base oil, suspension phase: Triblock copolymer PEOx-PPOy-PEOx were used as base fluid and obtained higher stability and good yield stress [9] $; \mathrm{Fe}_{3} \mathrm{O}_{4}$ hollow nanospheres was used to replace the carbonyl iron to obtain stronger structure chain and higher stability, through the simulation and experiments, the superparamagnetic fluid has 1.85 times larger yield stress than the nanoparticles based MF with excellent performance in stability $[10,11]$ . Also, a variety of different types of nonmagnetizable particles were added in the MR fluid, through particle mechanics modeling and 3D simulation analysis found that glass particles can enhance the rheological properties of the MR fluid [12, 13].

The present work focuses on experiment research to evaluate the influence of the nonmagnetizable glass particles to ball-shaped Carbonyl iron based MR fluid, aiming to achieve higher apparent viscosity MR fluid. The paper deals with different mass fraction of Carbonyl iron and glass particles, to achieve maximum improvement in apparent viscosity of the MR fluid.

\section{Experiment details}

\subsection{The preparation of MR fluid}

To understand the effect of glass particles on viscosity of MR fluid, two different MR samples $(60,65 \mathrm{~m} \%)$ of ball-shaped Carbonyl iron dispersed fluid was prepared. The MR fluid preparation procedure was as follows: (1). The ball-shaped carbonyl iron powder, shown in Fig. 1a, is dried under a vacuum degree of 0.1 $\mathrm{MPa}$ and a temperature of 700 degrees Celsius for $12 \mathrm{~h}$ to remove the physically adsorbed water on the surface; (2). Then, the dimer acid is added to Isopropanol, stir to get a mixture; (3). The dried Carbonyl iron powder is added to the mixture obtained in last step, stirring by using ultrasonic dispersion for 20 minutes, to obtain a suspension; (4). The suspension obtained in step 3 is put into a ball mill tank, ball milling at $200 \mathrm{rpm}$ for $6-8 \mathrm{~h}$; (5). The suspension obtained in step 4 is placed in an electric vacuum oven, the degree of vacuum of $0.1 \mathrm{MPa}, 70 \mathrm{de}-$ grees Celsius for $6 \mathrm{~h}$, after drying the resulting massive solid ground to powder that surfacetreated Carbonyl iron powder; (6). The dialyzed iron powder after surface treatment is added into the mixed solution obtained in step 5 , and the mixture is ultrasonically dispersed for 20 minutes after being uniformly stirred to obtain a suspension; (7). The suspension obtained in step 6 is placed in a ball mill tank, according to the mass ratio of the mixed material, ball milling at $300 \mathrm{rpm}$ for $12 \mathrm{~h}$, after grinding the ball is separated. That is MR fluid.

By adding different mass fraction glass particles, shown in Fig. 1b to obtain the experiment sample with varying glass particles mass fraction. In the experiment 5\%, 10\%, 15\%, 20\% mass fraction glass particles were added into the MR fluids, after stirring $6 \mathrm{~h}$ and ultrasonic dispersion for 20 minutes, the experiment samples are obtained, shown in Fig. 1c.

\subsection{The experiment equipment}

The MCR 302 rheometer is used in the experiment which is supplied by Anton Paar Inc.. As shown in Fig. 1d, the equipment mainly consisted of an operating panel, working plate, heating device, magnetizer, probe, motor. The operating temperature, applied currents and shear rates and other experimental parameters can be accurately controlled during the experimental process on the Anton Paar Rheo Compass software platform.

\section{Experiments and discussion}

MR fluid has many rheological properties parameters, in this paper, only the viscosity is discussed to evaluate the effect of the nonmagnetizable glass particles on the MR fluid, the dynamic viscosity of the MR fluid were analyzed through the experimental results. In the experimental process load currents are $0 \mathrm{~A}$, $0.5 \mathrm{~A}, 1 \mathrm{~A}, 1.5 \mathrm{~A}, 2 \mathrm{~A}, 2.5 \mathrm{~A}, 3 \mathrm{~A}$, the temperature is set 25 degrees Celsius. 

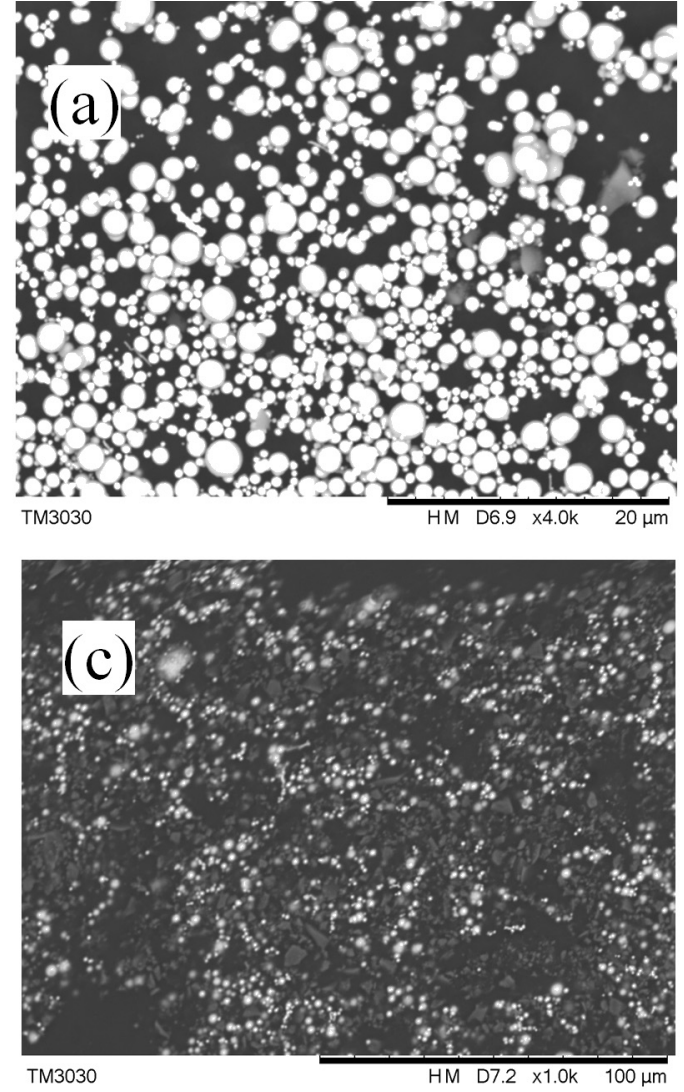

Fig.1 Experiment sample and its test equipment

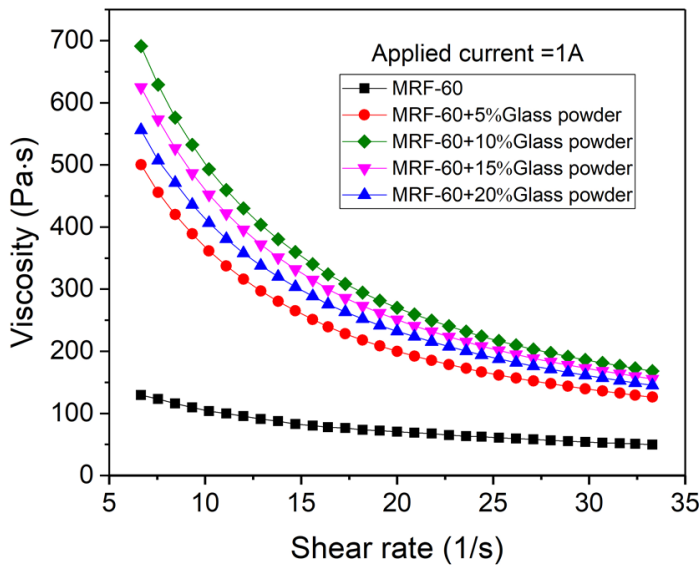

Fig. 2. Effect of glass particles on MR fluid's viscosity

\subsection{Glass particles effect to MRF-60}

MRF-60 is a $60 \%$ mass fraction of the ballshaped Carbonyl iron based MR fluid, the preparation process described above. When the shear rate is set at $6.67 \mathrm{1} / \mathrm{s}$, change the content of the glass particles to obtain the MR fluid, the viscosity curve is shown in Fig. 2.

It can be found that: (1). The apparent viscosity of the prepared MR fluid increases with
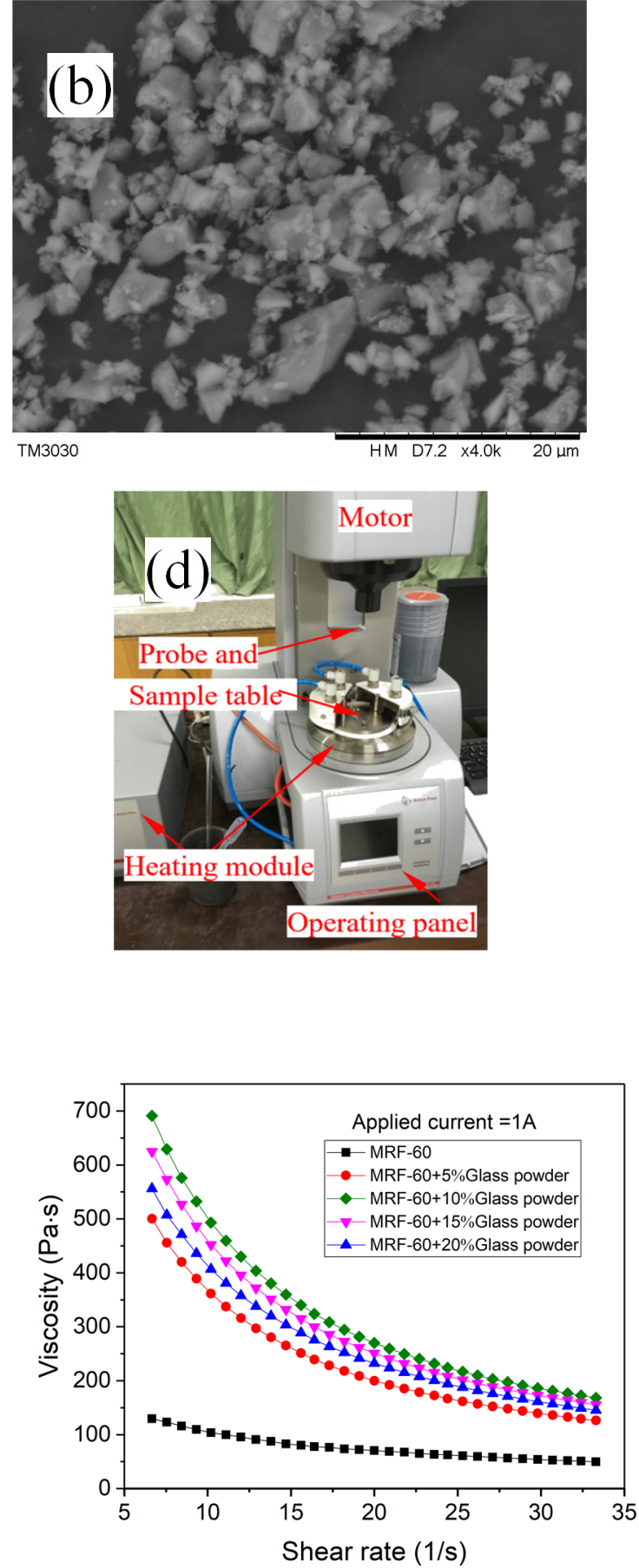

Fig. 3. Viscosity curves at different shear rates

the increase of the loading currents, and the value is $211.18 \mathrm{~Pa} \cdot \mathrm{s}$ at the current $\mathrm{I}=3 \mathrm{~A}$, which shows the MR fluid effect. (2). The viscosities are greatly improved by adding glass particles in MRF-60. At the current $I=3 \mathrm{~A}$, when add $5 \%, 10 \%, 15 \%, 20 \%$ glass particles to $\mathrm{MRF}$ 60 , the viscosities are $897.5 \mathrm{~Pa} \cdot \mathrm{s}, 1593.2 \mathrm{~Pa} \cdot \mathrm{s}$, 1407.9 Pa :s, 1126.4 Pa s, separately, compared with the viscosity of MRF-60, the viscosity is greatly improved. The maximum viscosity vari- 


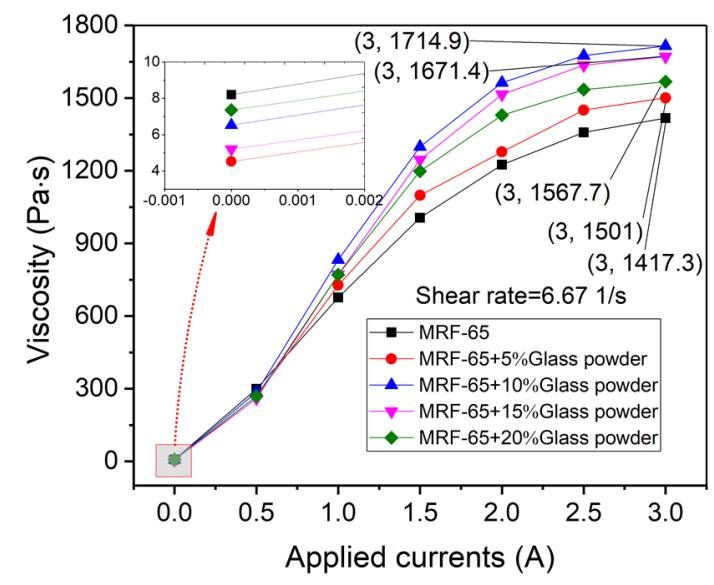

Figure 4. Effect of glass particles on MR fluid's viscosity

ation range is $1382.02 \mathrm{~Pa}$ s. (3). MRF-60 with $10 \%$ glass particles has the best rheological properties. From the viscosity curves, when the MR fluid is under the applied currents, the order of the viscosity is $V_{10 \%} \geq V_{15 \%} \geq V_{20 \%} \geq V_{5 \%} \geq V_{0 \%}$, which shows that too much glass particles have an obstructing effect on the composition of the carbonyl iron powder magnetic flux chain in the MR fluid. However, the proper amount of glass particles can enhance the intermolecular forces and promote the viscosity. (4). Without applied currents the glass particles almost have no effect on the viscosity of the MR fluid. When the loading current $I=0 \mathrm{~A}$, the viscosity of MR fluids is small, all of them are in the range of 3-10 $\mathrm{Pa} \cdot \mathrm{s}$. So a better output variable damping force can be get.

Fig. 3 shows the viscosity curves of different experimental samples at different shear rates. The MR fluid shows shear thinning phenomenon, where viscosity decreases due to breaking of field induced chain aggregates and $F_{M} \leq F_{H}$ [9]. When the shear rate is greater than 30 , the phenomenon of shear thinning becomes gentle, and the experimental results show the same variation with the reference [9]. The viscosity dynamic variation range of the MR fluid containing glass particles is larger than which of MRF-60 without glass particle under the same experimental parameters.

\subsection{Glass particles effect to MRF-65}

MRF-65 donates the ball-shaped Carbonyl iron is $65 \%$ mass ratio in MR fluid. When the shear rate is set at $6.67 \mathrm{1} / \mathrm{s}$, changing the content of glass particles in MR fluid, the viscosity curve is obtained and shown in Fig. 4, which has similar phenomena with MRF-60: (1). The apparent viscosity of MR fluid increases with the increase of the loading currents I. (2). MRF65 containing $10 \%$ glass particles has the best rheological properties. When the current $I=3 \mathrm{~A}$,

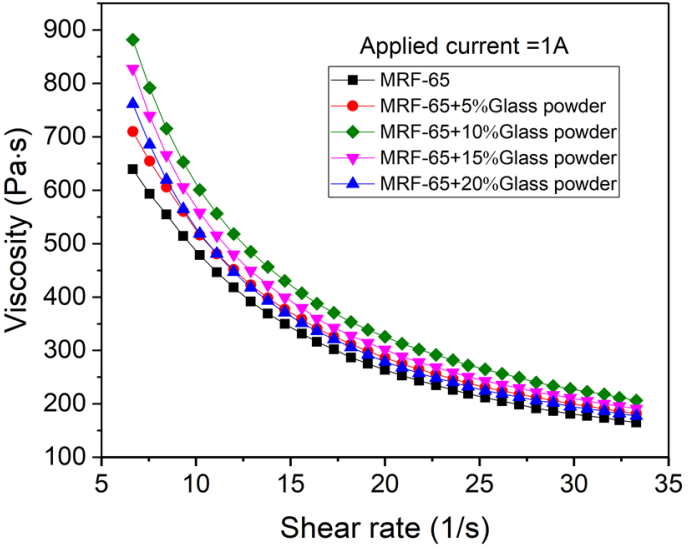

Figure 5. Viscosity curves at different shear rates

add $0 \%, 5 \%, 10 \%, 15 \%, 20 \%$ mass fraction glass particles to MRF-65 to get experiment samples, and the viscosity is $1417.3 \mathrm{~Pa} \cdot \mathrm{s}, 1501 \mathrm{~Pa} \cdot \mathrm{s}$, $1714.9 \mathrm{~Pa} \cdot \mathrm{s}, 1671.4 \mathrm{~Pa} \cdot \mathrm{s}, 1567.7 \mathrm{~Pa} \cdot \mathrm{s}$ separately. The maximum impact range on the viscosity is 297.6Pa.s. (3). The glass particles almost have no effect on the viscosity of the MR fluid without applied currents.

Fig. 5 shows the viscosity curves of different experimental samples at different shear rates. The trend of the curves is similar to that in Fig. 3.

Comparing Fig. 2 with Fig. 4, it can be found that the viscosity of the experimental sample increases with the increase of iron, but the influence of glass particles on the viscosity of MR fluid becomes smaller. The reason is due to the increase of iron, the rheological increases greatly, which reduces the influence of the glass particles on the viscosity.

\section{Conclusion}

In this paper, two kinds of MR fluids with different iron content were prepared. The influence of non-magnetic glass particles on the viscosity of MR fluid was studied by changing the glass particles mass content. The proper amount of glass particles can enhance the intermolecular force and promote the viscosity. When the content of glass particles is $10 \%$, the influence on the viscosity is the largest, the influence reaches 7 times. Compared with MRF60 , glass particles in MRF-65 promote a smaller range in viscosity. Therefore, in cases when the content of iron powder is not very high, the rheological properties of MR fluids can be improved by adding nonmagnetizable particles.

\section{Acknowledgement}

This work was supported by National Natural Science Foundation of China (No. 51305079), 
Natural Science Foundation of Fujian Province (No. 2015J01180) and outstanding young talent support program of Fujian Provincial Education Department (No. JA14208, JA14216). These financial supports are gratefully acknowledged.

\section{References}

1. Stephen G. Sherman, Andrew C. Becnel, Norman M. Wereley J.Magn. Magn. Mater. 380, 98, 2015.

2. Wan H K, Jhin H P, Suresh K, et al. Sens. Actuat. A Phys., 255, 104, 2017.

3. Attia E.M., Elsodany N.M., El-Gamal H.A., et al., Alexandria Eng. J, 5,.189, 2017.

4. Satyajit R. Patil, Kanhaiya P.Powar, Suresh M.Sawant, Appl. Therm. Eng., 98, 238, 2016.

5. Andrew C. B, Stephen S, Hu W, Norman M.W. , J.Magn. Magn. Materi., 380, 90, 2015.

6. Saraswathamma K., Sunil Jha, P. Venkateswara Rao., Materials Today: Proceedings, 4 (2), pp.1478, 2017.

7. Anwesa Barman, Manas Das., Precision Eng., 51, 145, 2017.
8. Noor Jahan, Saurabh Pathak, Komal Jain, et al. Colloids Surf.A: Physicochem. Eng. Aspects, 529, 88, 2017.

9. Keshvad Shahrivar, Juan de Vicente, Smart Mater. Struct., 23, 1, 2014.

10. Xiaohui Ruan, Lei Pei, Shouhu Xuan, et al. J.Magn. Magn. Mater., 429, 1, 2017.

11. Lei Pei, Haoming Pang, Xiaohui Ruan,et al. "Magnetorheology of a magnetic fluid based on $\mathrm{Fe} 3 \mathrm{O} 4$ immobilized $\mathrm{SiO} 2$ core-shell nanospheres: experiments and molecular dynamics simulations", Royal Society of Chemistry, 7, pp.8142-8150.

12. Ulicny, J. C., K. S. Snavely, M. A. Golden, D. J. Klingenberg. (2010) "Enhancing magnetorheology with nonmagnetizable particles," Applied Physics Letters, 96 (23) :246.

13. Wilson BT, Klingenberg DJ. (2017) "A jamming-like mechanism of yield-stress increase caused by addition of nonmagnetizable particles to magnetorheological suspensions", Journal of Rheology, 61 (4), pp.601-611. 